DOI: 10.37943/AITU.2021.10.44.003

\author{
S. Burbekova \\ Candidate of philological sciences, Associate Professor of the \\ Department of Social Sciences \\ saule.burbekova@astanait.edu.kz,orcid.org/0000-0002-0624-6226 \\ Astana IT University, Kazakhstan
}

\title{
FACTORS FOR ACHIEVING LEARNING OUTCOMES: OVERVIEW OF ASTANA IT UNIVERSITY'S EXPERIENCE
}

\begin{abstract}
The article gives an overview of Astana IT University's (AITU) experience in performing the teaching conditions for achieving the learning outcomes. The introduction of a competency-based approach to the formation and assessment of learning outcomes has led to a new system of training and assessment tools. Stakeholdership as a modern mechanism, the problem of focusing on employers' needs, the stages of the education programme (EP) development and the criteria for assessing the learning outcomes achievement are discussed in details. The quality of education is determined by the quality of the results of the educational process, where the educational achievements of students and the qualifications of graduates become the main components of education quality. The purpose of the study is aimed to summarize the practice of using assessment tools as the key factors and conditions for establishing learning outcomes. The research methodology used is quantitative and qualitative data analysis as well as analysis of class observation in AITU done within the research on learning outcomes achievement. The choice and design of teaching technology are primarily determined by the type of students' competencies, characteristics of the planned learning outcomes for each level of competence (knowledge, skills, and experience). Constant improvement of EP content and educational technologies as a key factor of education services quality is a vital demand.
\end{abstract}

Key words: stakeholdership, assessment tools, learning outcomes, students' competencies, design of teaching technology, competency-based approach.

\section{Introduction}

Quality is dynamic and therefore constantly changing concepts and depends on who asks the question and what views on the education goals are. Different stakeholders' points of view are the attributes of education quality. The problem of education quality is solved by taking into account the key ideas of the stakeholder theory, which main idea is to pay attention to the diverse expectations of different parties [1].

Stakeholdership is a modern mechanism that allows the state and business to formulate their "order" for education to manage the quality of education, which characterizes the quality of achieving the education goal and the education result, the compliance of the education provided with the needs of all stakeholders, represented by students, teaching staff and employers.

Understanding of the value, role, and results of learning outcomes have undergone significant changes over the past decades when the EP graduates are competent and able to solve nonstandard situations. The quality of educational services and compliance of the EP content is 
determined by conditions and results of their implementation with established norms, state requirements, social and personal expectations. The concept of the program contains basic information for stakeholders (students, parents, employers etc.).

\section{Literature review}

A number of researches has been done on the related topic. Richard and Shavelson in [2] state that learning outcomes could be seen by their direct link to the content of the discipline or subject area and measuring student learning through assessment techniques that emphasize learning outcomes such as critical thinking, analytical reasoning, problem solving, and communication.

According to Hussey and Smith in [3] learning outcomes have become widely used in higher education, but also misused to the point of being controversial. As a central component of national qualifications frameworks, the establishment of learning outcomes requires $\mathrm{HE}$ institutions to design and organize their study programs in line with a learning outcome paradigm. Prøitz in [4] illuminates the phenomenon of learning outcomes within a wide range of studies, where the phenomenon has been examined in various ways based on a document analysis in which the concept is discussed. In [5] Dawkins, Hurley, \& Noonan made great emphasis on courses and subjects' learning outcomes in terms of what learners need to achieve and on what they will be assessed on.

Harvey and Williams state in [6] that in many countries, the interest in learning outcomes is integrated in existing quality assurance procedures for improving and securing academic standards with respect to what students learn.

Pascarella and Terenzini identify learning outcomes as a notion expressed in terms of what students should know, their skills, and competencies, while quality assurance procedures are usually expressed in form of organizational procedures, rules, and regulations [7].

According to Dill and Beerkens, quality assurance has been one of the most significant activities as a response to the concerns about the need for more effective and efficient delivery of educational provisions in HE [8].

In [9] Aamodt and Frølich (2016) attracted much interest to the concept of developing more specific learning outcomes, where learning outcomes are perceived as more useful and relevant than traditional quality assurance approaches. They assume that if learning outcomes are seen as parts of existing quality assurance procedures, they might be perceived to be tools and measures more related to the need for organizational and managerial control rather than for teaching and learning improvement.

Lile, R., \& Bran C. in [10] express concern for the assessment of learning outcomes, reinforced by the requirement expressed by society and discuss the comprehensive instruments for evaluation that can be used in all academic fields, highlighting both the learning outcomes and the learning process.

The effectiveness of learning outcomes from the students' perspective and comments from stakeholders demonstrates that the graduate students lacked basic knowledge and had difficulties in integrating knowledge learned or gained to solve engineering problems. In [11] the content of the curriculum is suggested to be revised by introducing new courses which integrate students' knowledge and changing instructional methods. 


\section{Problem statement}

Demand and market competitiveness for educational services is determined by the maximum compliance with the potential stakeholders' requests and EP uniqueness in comparison with similar programs of other universities. The problem of creating a higher education model aimed at ensuring flexibility, mobility in relation to the labor market challenges is becoming vital to meet the demands of the labor market, focused on employers' needs.

However, there can be noted a number of problems that require special attention in the EP design. It is a small interface with professional standards and labor functions, the need for constant updating of the EP content in connection with the rapid rate of information inadequacy. Continuous updating of EP content and improvement of educational technologies and educational process organization become a real challenge for modern education. The sign of quality assurance is the presence of active, systemic interaction and integration of business, labor market, and education. The implementation of this principle is often difficult due to weak ties and lack of cooperation between universities, labor markets and businesses to build a coherent environment within the framework of such integration.

Most often, indicators of the EP's goal achievement, which are expert data obtained by polling (questionnaires, interviews) of employers regarding the quality of training graduates for professional activity, as well as objective data on the graduates' achievements during their professional careers, do not always reflect the true picture or even demonstrate a lack of full satisfaction. In the result of the answer analysis and the study of the employers', students', and teaching staff opinions about the training quality there are proposals for adjusting the goals and content of the educational program.

\section{Research methodology}

To determine the presence of favorable conditions for the EP development, we analyzed the stages and conditions of EP development in AITU and NU (Nazarbayev University). To what extent was the sequence of the EP development followed, whether the study was carried out and whether the needs of stakeholders were considered while forming the EP goals. Mechanism used for planning learning outcomes to achieve the EP goals and the definition of indicators and criteria for assessing learning outcomes. Consistency of methods and means of assessing learning outcomes for checking the achievement of EP goals.

The analysis of the EPs concept was also carried out in accordance with the university mission, the correspondence of the graduate competency model to the list of planned competencies, as the cumulative educational result of EP mastering. Does the main aim of the EP reflect the unique competencies of graduates, based on the EP goals and planned results? Educational Programs Computer science of AITU and NU have been analyzed on the preserving components and stages of EP development, compliance of the EP graduates' competencies according to requirements of the State Educational Standard; Professional standards; special requirements of potential employers; the needs of the regional labor market.

The comparison of Computer Science EPs' Curriculum of NU and AITU is presented in table 1. 
Table 1. The table of courses taught at Nazarbayev University and Astana IT University

\begin{tabular}{|c|c|c|}
\hline \multicolumn{3}{|c|}{ Year 1} \\
\hline Module & NU courses & AITU courses \\
\hline $\begin{array}{l}\text { Module of general } \\
\text { courses }\end{array}$ & $\begin{array}{l}\text { History of Kazakhstan } \\
\text { Communications } 1\end{array}$ & $\begin{array}{l}\text { Foreign Language (English) } \\
\text { Cultural studies } \\
\text { Modern history of Kazakhstan }\end{array}$ \\
\hline $\begin{array}{l}\text { Module of } \\
\text { basic courses }\end{array}$ & $\begin{array}{l}\text { Calculus I-II } \\
\text { Physics I-II with Lab } \\
\text { Probability }\end{array}$ & $\begin{array}{l}\text { Mathematical Analysis 1-2 } \\
\text { Discrete mathematics } \\
\text { Algebra and geometry }\end{array}$ \\
\hline $\begin{array}{l}\text { Module of } \\
\text { professional courses }\end{array}$ & $\begin{array}{l}\text { Programming for Scientists and } \\
\text { Engineers } \\
\text { Performance and Data } \\
\text { Structures }\end{array}$ & $\begin{array}{l}\text { Information and Communication Technologies } \\
\text { Fundamentals of programming C++ } \\
\text { Fundamentals of programming Java } \\
\text { Introduction to WEB (HTML, CSS, JavaScript) } \\
\text { Object-oriented programming C++ } \\
\text { Object-oriented programming Java } \\
\text { Web technologies (PHP) } \\
\text { Ruby Programming Language } \\
\text { Algorithms and Data Structures }\end{array}$ \\
\hline \multicolumn{3}{|c|}{ Year 2} \\
\hline $\begin{array}{l}\text { Module of general } \\
\text { courses }\end{array}$ & $\begin{array}{l}\text { Communications } 2 \\
\text { Kazakh Language 1- } 2\end{array}$ & $\begin{array}{l}\text { Political science } \\
\text { Sociology } \\
\text { Kazakh (Russian) Language }\end{array}$ \\
\hline $\begin{array}{l}\text { Module of } \\
\text { basic courses }\end{array}$ & $\begin{array}{l}\text { Linear Algebra with } \\
\text { Applications } \\
\text { Discrete Mathematics } \\
\text { Formal Languages } \\
\text { Research Methods } \\
\text { Entrepreneurship } \\
\text { Natural Science (Elective 1-2) }\end{array}$ & $\begin{array}{l}\text { Psychology } \\
\text { Research Methods and Tools } \\
\text { Theory of Probability and Mathematical Statistics } \\
\text { Information Theory } \\
\text { Network Application Performance Engineering } \\
\text { Mastering Design Thinking } \\
\text { Communication Management } \\
\text { Technological Enterpreneurship } \\
\text { Project management }\end{array}$ \\
\hline $\begin{array}{l}\text { Module of } \\
\text { Professional courses }\end{array}$ & $\begin{array}{l}\text { Computer Systems \& } \\
\text { Organization } \\
\text { Programming Languages } \\
\text { Algorithms } \\
\text { Microcontrollers with Lab } \\
\text { Artificial Intelligence } \\
\text { Database Systems } \\
\text { Software Engineering } \\
\text { Computer Networks } \\
\text { Operating Systems }\end{array}$ & $\begin{array}{l}\text { Computer Organization and Architecture } 1 \text {-2 } \\
\text { Software Architecture } \\
\text { Network Application Architecture } \\
\text { PL/SQL Programming 1-2 } \\
\text { Python Programming 1-2 } \\
\text { Database Management Systems } \\
\text { Digital Systems } \\
\text { Software Design Pattern } \\
\text { Operating Systems (Windows / Linux administration) } \\
\text { Operating Systems Security } \\
\text { Computer Networks (Cisco CCNA + R\&S) } \\
\text { Mobile Development 1-2 (Android, iOS) } \\
\text { Software Factory (project) } \\
\text { Advanced programming } 1 \text {-2 } \\
\text { Robotics and Mechatronics } \\
\text { Information Security Fundamentals } \\
\text { Applied applications analysis } \\
\text { Machine Learning Algorithms } \\
\text { Software Quality Assurance and Testing } \\
\text { Cloud computing applications } \\
\text { Embedded systems design } \\
\text { Network Application Security } \\
\text { Distributed algorithms and parallel computing }\end{array}$ \\
\hline
\end{tabular}


The end of the table 1.

\begin{tabular}{|l|l|l|}
\hline \multicolumn{2}{|c|}{ Year 4 } \\
\hline & Senior Project I - 2 & \\
\hline & Technical Elective 1 - 2-3-4 & \\
\hline & Free Elective 1 & \\
\hline & Social Science & \\
\hline & Ethics & \\
\hline $\begin{array}{l}\text { Total number of } \\
\text { Credits: }\end{array}$ & 240 ECTS \\
\hline
\end{tabular}

The content of Computer Science EPs of both Universities focuses on the study of computers and computational systems, computer scientists deal mostly with software and software systems; this includes their theory, design, development, and application. Principal areas of study within Computer Science include artificial intelligence, computer systems, and networks, security, database systems, human-computer interaction, vision and graphics, numerical analysis, programming languages, software engineering, bioinformatics, and theory of computing.

The purpose of Educational Program 6B06103 Computer science of AITU is to train IT professionals who can solve a wide range of applied tasks, for example, building web services, data analysis and machine learning tasks, managing software projects, and their development processes.

The Computer Engineering program of NU follows the outcome-based teaching and learning approach and focuses on skill development that enables the NU graduates to compete internationally in the job market, research, and to be entrepreneurs who lead change in the local contexts. The program positions by integrating inquiry, research, and projects in solving relevant problems facing society today.

We can clearly see that the purposes of both programs are aimed at forming applied skills of IT professionals for solving professional tasks, such as data analysis, managing software projects, and research.

Learning outcomes are achieved via EP courses as it is presented in Tables 2 and 3. 
Table 2. Outline of learning outcomes of AITU courses

\begin{tabular}{|c|c|c|}
\hline Learning outcomes & Course title & $\begin{array}{l}\text { Discipline } \\
\text { numbers }\end{array}$ \\
\hline $\begin{array}{l}\text { 1. The ability of real use of the state language, the } \\
\text { language of international communication and a foreign } \\
\text { language in professional activities. }\end{array}$ & Professional English & 1 \\
\hline $\begin{array}{l}\text { 2. Able to increase the level of mathematical skills to } \\
\text { improve the logic of programming and writing software. }\end{array}$ & $\begin{array}{l}\text { Algebra and Geometry } \\
\text { Discrete Mathematics } \\
\text { Mathematical Analysis } \\
\text { Theory of Probability and Mathematical } \\
\text { Statistics }\end{array}$ & 5 \\
\hline $\begin{array}{l}\text { 3. The ability to use the basic provisions and methods } \\
\text { for solving managerial problems, the ability to carry out } \\
\text { project documentation in the software environment of } \\
\text { computer graphics for various types of projects. }\end{array}$ & $\begin{array}{l}\text { Technological Enterprise } \\
\text { Design Pattern (Java) } \\
\text { Project Management }\end{array}$ & 3 \\
\hline $\begin{array}{l}\text { 4. Learn the basic principles of computer networks, the } \\
\text { ability to administer networks, increase the security and } \\
\text { efficiency of network applications. }\end{array}$ & $\begin{array}{l}\text { Networks and Telecommunications } \\
\text { Network security }\end{array}$ & 2 \\
\hline $\begin{array}{l}\text { 5. Able to develop complex algorithms and highly loaded } \\
\text { applications processing large data streams increasing } \\
\text { efficiency and availability. }\end{array}$ & $\begin{array}{l}\text { Algorithms and Data Structures } \\
\text { Python Programming Technologies } \\
\text { Functional programming } \\
\text { Introduction to Machine Learning }\end{array}$ & 4 \\
\hline $\begin{array}{l}\text { 6: The ability to develop information and software infor- } \\
\text { mation systems based on modern methods and develop- } \\
\text { ment tools. }\end{array}$ & $\begin{array}{l}\text { Mobile Development (Android) (iOS) } \\
\text { Web technologies (PHP) } \\
\text { Spring Cloud and Spring Data } \\
\text { Object Oriented Programming C }++, \text { (Jav }\end{array}$ & 6 \\
\hline $\begin{array}{l}\text { 7. The ability to carry out a description of applied } \\
\text { processes and information support for solving applied } \\
\text { problems. }\end{array}$ & Technological Enterprise & 1 \\
\hline $\begin{array}{l}\text { 8. Able to design and develop user interfaces, commer- } \\
\text { cial software components, databases and embedded } \\
\text { software modules. }\end{array}$ & $\begin{array}{l}\text { Introduction to the Web (HTML, CSS, } \\
\text { JAVASCRIPT) } \\
\text { Human-Computer Interaction }(\mathrm{HCl})\end{array}$ & 2 \\
\hline $\begin{array}{l}\text { 9. Able to create your own algorithms by focusing on } \\
\text { speed of execution and efficiency for use in software } \\
\text { development. }\end{array}$ & $\begin{array}{l}\text { Python Programming Technologies } \\
\text { Aspect Oriented Programming } \\
\text { Fundamentals of programming }(\mathrm{C}++) \text {, } \\
\text { (Java) } \\
\text { Cloud computing } \\
\text { Object Oriented Programming C ++, } \\
\text { (Java), Parallel computing } \\
\text { Functional programming } \\
\text { Ruby on Rails Framework } \\
\text { C \# programming technology }\end{array}$ & 11 \\
\hline $\begin{array}{l}\text { 10. The ability to use modern programming environ- } \\
\text { ments for the design and implementation of databases. }\end{array}$ & $\begin{array}{l}\text { (DBMS) Database Management System } \\
\text { Oracle, POSTGRE }\end{array}$ & 2 \\
\hline $\begin{array}{l}\text { 11. Able to learn the basic principles of computer } \\
\text { architecture and administer the server depending on the } \\
\text { operating system }\end{array}$ & $\begin{array}{l}\text { Computer architecture and Operating } \\
\text { Systems } \\
\text { Introduction to Linux Systems }\end{array}$ & 2 \\
\hline $\begin{array}{l}\text { 12: The ability to develop, implement and adapt applica- } \\
\text { tion software. }\end{array}$ & $\begin{array}{l}\text { Ruby Programming Language } \\
\text { Mobile Development } 1 \text { (Android) (iOS) } \\
\text { Django Framework } \\
\text { Web technologies (PHP) } \\
\text { C \# programming technology } \\
\text { Spring Cloud and Spring Data } \\
\end{array}$ & 7 \\
\hline $\begin{array}{l}\text { 13. The ability to learn the basics of information security } \\
\text { to create reliable software, protect networks and cy- } \\
\text { ber-attacks. }\end{array}$ & Information Security & 1 \\
\hline
\end{tabular}


Table 3. Outline of learning outcomes of NU courses

\begin{tabular}{|c|c|c|}
\hline Learning outcomes & Course title & $\begin{array}{c}\begin{array}{c}\text { Discipline } \\
\text { numbers }\end{array} \\
\end{array}$ \\
\hline $\begin{array}{l}\text { Able to understand the basics of calculus concepts } \\
\text { and problem-solving methods in variety of situations, } \\
\text { particularly in expressing mathematical ideas clearly, } \\
\text { precisely, and unambiguously; } \\
\text { The ability to understand formal languages and } \\
\text { mathematical models of computation and foundations of } \\
\text { probability theory. }\end{array}$ & $\begin{array}{l}\text { Calculus } \\
\text { Discrete Mathematics } \\
\text { Linear Algebra with Applications } \\
\text { Formal Languages } \\
\text { Probability }\end{array}$ & 6 \\
\hline $\begin{array}{l}\text { Able to understand the basics of algorithms using the } \\
\text { C programming language, understand the concept of } \\
\text { abstract data types, and implement good data structures. }\end{array}$ & $\begin{array}{l}\text { Programming for Scientists and Engi- } \\
\text { neers } \\
\text { Performance and Data Structures }\end{array}$ & 2 \\
\hline $\begin{array}{l}\text { Able to understand the fundamental concepts of } \\
\text { computer architecture, to analyze computer systems (or } \\
\text { subsystems) and compare them based on performance } \\
\text { and cost }\end{array}$ & $\begin{array}{l}\text { Performance and Data Structures } \\
\text { Computer Systems and Organizations }\end{array}$ & 2 \\
\hline $\begin{array}{l}\text { The ability to use a very large number of programming } \\
\text { languages and gain experience on proper programming } \\
\text { practices and style. }\end{array}$ & Programming Languages & 1 \\
\hline $\begin{array}{l}\text { Able to understand the common strategies for } \\
\text { designing efficient algorithms, and the analysis of their } \\
\text { performance in terms of time and memory. }\end{array}$ & Algorithms & 1 \\
\hline $\begin{array}{l}\text { Able to understand the basic principles in artificial } \\
\text { intelligence and learn simple representation schemes, } \\
\text { problem-solving paradigms, constraint propagation, and } \\
\text { search strategies. }\end{array}$ & Artificial Intelligence & 1 \\
\hline $\begin{array}{l}\text { The ability to use database management systems, with } \\
\text { coverage of physical characteristics of storage media. }\end{array}$ & Database Systems & 1 \\
\hline $\begin{array}{l}\text { Able to illustrate software process and project } \\
\text { management techniques, various design and } \\
\text { architecture techniques, and introduces software testing } \\
\text { management, and analysis tools. }\end{array}$ & Software Engineering & 1 \\
\hline $\begin{array}{l}\text { Able to understand the basic concepts of data } \\
\text { communications }\end{array}$ & Computer Networks & 1 \\
\hline $\begin{array}{l}\text { Able to understand the concepts and building blocks, } \\
\text { apply and extend these concepts through a focus on } \\
\text { systems programming. }\end{array}$ & Operating Systems & 1 \\
\hline $\begin{array}{l}\text { Able to understand the fundamentals of critical reading, } \\
\text { writing and research document analysis as well as } \\
\text { composition of scientific papers. }\end{array}$ & Research Methods & 1 \\
\hline
\end{tabular}

The correspondence analysis of formulation EP learning outcomes of both universities carried out demonstrates:

- Correspondence of learning outcomes to the goals of the program;

- Clear formulation of learning outcomes for quality monitoring;

- Availability of professional and general competencies in the training area;

- Achievability of learning outcomes;

- Use of action verbs (activity) in the EP learning outcome formulation.

The significant differences are reflected in a number of courses for coining the learning outcomes within EPs. 


\section{Discussion}

The analysis of the EP goals' formation demonstrates the sequence in the development of EP content, taking into account the stakeholders' proposals. The concept of the program correlates with the university mission, aimed at preparing graduates for the Digital transformation of Kazakhstan. In AITU, students training at IT companies is widely used as one of the elements of dual education. The graduate competency model meets the requirements of professional standards, special requirements of potential employers, and the regional labor market.

Each objective of the EP corresponds to one or more stakeholders' requests and is achievable, verifiable, and measurable. In [12] it is highlighted, that the successful students' actions in knowledge assessment, problem-solving and task completing (skills), repeated and successful practical actions expected in future professional activity (experience) are the indicators of the learning outcomes achievement.

The author of the article mainly aimed at focusing on the criteria for assessing the learning outcomes achievement, the effectiveness of the assessment mechanism. Based on the analysis of the course syllabi content, it can be concluded that the achievement of EP learning outcomes is controlled and integrally assessed during mastering the course.

Analysis of the conformity of the measuring assessment tools demonstrates that the components of learning outcomes are realistic (achievable) and assessed in the process of current and final assessment using a point-rating system. The percentage of level proportion is presented in Table 4.

Table 4

\begin{tabular}{|l|l|c|}
\hline \multicolumn{1}{|c|}{ Level } & \multicolumn{1}{|c|}{ Activity } & \% \\
\hline knowledge & facts, principles, theories and practices & $34 \%$ \\
\hline skills & ability to apply knowledge to fulfill tasks and solve problems & $42 \%$ \\
\hline experience & $\begin{array}{l}\text { ability (skill) to successfully solve problems in the field of professional } \\
\text { activity. }\end{array}$ & $24 \%$ \\
\hline
\end{tabular}

Developers of courses (modules) assess the achievement of the constituent learning outcomes in the course assessment using certain indicators and criteria. It is mandatory to have a method description for assessing learning outcomes that guarantee their adequacy to the stated goals.

Indicators of learning outcomes achievement are assessment of successful practical actions at the end of course completion. The ability of graduates to solve problems of a research and design nature (analysis, synthesis) in real or close to workplace conditions is a reliable indicator. The formation of learning outcomes corresponds to the following principles: each category (knowledge, skill, experience) includes the corresponding verb and a specific description of the planned result. Bloom's taxonomy was widely used in formulating these indicators. For example, verbs used to formulate the indicators: to calculate, build, show, solve, prepare, choose, etc.

Assessment criteria descriptors can be classified according to the level and types of actions and presented in Table 3. 
Table 5. Descriptors of assessment criteria

\begin{tabular}{|c|c|c|}
\hline Level & Types of action & Descriptors to formulate assessment criteria \\
\hline knowledge & $\begin{array}{l}\text { actions reflecting work with } \\
\text { information, performance of various } \\
\text { mental operations: reproduction, } \\
\text { understanding, analysis, comparison, } \\
\text { assessment, etc. }\end{array}$ & $\begin{array}{l}\text { isolates the parts of the whole, identifies relationships; } \\
\text { defines the principles of the organization of the whole, } \\
\text { sees errors and omissions in a specific situation; } \\
\text { reproduces specific facts, methods and procedures, } \\
\text { basic concepts, rules and principles of the studied } \\
\text { subject; explains facts, rules, principles; }\end{array}$ \\
\hline skill & $\begin{array}{l}\text { characteristics of skills acquired in } \\
\text { the process of using and applying the } \\
\text { general/ basic skills. }\end{array}$ & $\begin{array}{l}\text { applies laws, theories in specific practical situations, } \\
\text { distinguishes between facts and effects; converts } \\
\text { material }\end{array}$ \\
\hline experience & $\begin{array}{l}\text { characteristics of skills acquired in } \\
\text { the process of solving professional } \\
\text { problems. }\end{array}$ & $\begin{array}{l}\text { uses concepts and principles in new situations; } \\
\text { evaluates the significance of the data; suggests a } \\
\text { plan for conducting an experiment or other action; } \\
\text { draws up schemes of tasks for a specific type of } \\
\text { activity; evaluates the logic of actions; evaluates the } \\
\text { consistency of findings with available data; evaluates } \\
\text { the significance of a particular product of activity; } \\
\text { arrives, etc. }\end{array}$ \\
\hline
\end{tabular}

The implementation of the competency-based approach in training IT students at AITU is carried out through the design of new educational materials in accordance with modern trends in science and job market; the use of interactive teaching methods that involve students in active work to solve specific professional and educational problems; design of new didactic tools based on integral teaching methods that allow to achieve planned results (cases, tasks, tests, electronic tools). All methods used are most consistent with the personality-oriented and competency-based approaches, since they involve co-education (collective, collaborative learning). The teacher often acts as an organizer of the learning process, a group leader, a facilitator, and a creator of conditions for student initiative. He/she plays the main role in designing the content of the course training, choosing concepts and learning technologies, the level of complexity of the program, etc. The teacher can quickly assess the quality of education and make the necessary adjustments to the educational process in order to improve it.

Lesson observation of AITU teaching staff demonstrates the usage of a wide variety of teaching tools such as interactive lectures, video and audio materials analysis, case study, situation analysis, role-play, group discussion, competition, testing, press conference, feedback techniques, situation analysis, round table, problem-solving, discussion of developed options, analysis of specific situations, research work, brainstorming, dispute, debate, forum, etc.

Tasks performed at practical lessons are used to establish the correct sequence, to clarify the influence of various factors; to describe the algorithm for performing an action, to find errors in a sequence, to determine the correct option for a sequence of actions, to indicate the possible influence of factors, to make a decision in a non-standard situation, assignments for assessing the consequences of decisions made, tasks for assessing the effectiveness of the action, etc.

The evaluation tool most often used in AITU learning process is oral questioning, tests; multilevel tasks; case task; essays and other creative works, such as portfolio, round table, discussion, dispute, debate; and other gaming technologies; research project (presentation, report, communication), testing, individual interview, written answers to questions, practical tasks, project work etc.

Assessment tools include a description of the assessment scales, procedures for assessing learning outcomes in a course (module). In EP implementation, the assessment tools form a 
whole fund of assessment tasks, as well as descriptions of forms and procedures designed to determine the quality of course mastering by students.

The assessed knowledge and skills can be classified in several groups - this is factual knowledge that must be constantly used in professional activities ("for memory"); cognitive skills for dividing information into parts, identifying the relationships between them, understanding and explaining the principles of organizing the whole, etc.; collection and transformation of information from different sources, systemic structuring of new information explaining a phenomenon or event (synthesis); by assessing the value of an object/phenomenon for a specific purpose, determining and making a judgment about the integrity of an idea/method / theory based on insight into the essence of phenomena and their comparison, etc. (grade); to attract information and intellectual course tools to solve problems; the ability to solve typical educational and professional tasks, the ability to solve a local, but atypical professional problem etc.

To carry out the final assessment of the competence formation, the defense of individual or group projects, the design and defense of reports, portfolios, case problems, interviews, essays, portfolio etc. are frequently used.

\section{Conclusion}

The quality of education is a complex characteristic of educational activities and training of a student, expressing the degree of achievement of the planned results of an educational program. The content of educational programs should be formed based on professional standards. The formulation of learning outcomes should clearly correlate with the levels of competence development and with the main stages of the knowledge acquisition process.

The quality of education is determined by the quality of the results of the educational process, where the educational achievements of students and the qualifications of graduates become the main components of education quality.

The compliance of planned results with professional standards; programs of academic courses (modules), as well as assessment materials are the key criteria for to achieve planned learning outcomes by students.

The analysis done proves that EP development in AITU has an effective mechanism for ensuring the EP goals' achievement and adjustment. Monitoring and evaluating the achievement of EP goals are associated with supporting the graduates' professional career. The introduction of a competency-based approach to the formation and assessment of learning outcomes has led to a new system of training and assessment tools. The choice and design of innovative technology are primarily determined by the type of students' competencies, characteristics of the planned learning outcomes for each level of competence (knowledge, skills, and experience). To adjust the constituent learning outcomes, it is necessary to monitor the achievement of the constituent learning outcomes, improve the content of the course (modules) and educational technologies.

\section{References}

1. Freeman, R.E. (1984). Strategic management: A stakeholder approach. Boston: Harper Collins.

2. Shavelson, R.J. (2010). On the measurement of competency. Empirical research in vocational education and training, 2(1), 41-63.

3. Hussey, T., \& Smith, P. (2008). Learning outcomes: a conceptual analysis. Teaching in higher education, 13(1), 107-115. doi: 10.1080/13562510701794159.

4. Prøitz, T.S. (2010). Learning outcomes: What are they? Who defines them? When and where are they defined?. Educational assessment, evaluation and accountability, 22(2), 119-137. doi: 10.1007/ s11092-010-9097-8. 
5. Dawkins, P., Hurley, P., \& Noonan, P. (2019). Rethinking and revitalising tertiary education in Australia.

6. Harvey, L., \& Williams, J. (2010). Fifteen years of quality in higher education.

7. Pascarella, E.T., \& Terenzini, P.T. (2005). How College Affects Students: A Third Decade of Research. Volume 2. Jossey-Bass, An Imprint of Wiley. 10475 Crosspoint Blvd, Indianapolis, IN 46256.

8. Dill, D. D., \& Beerkens, M. (Eds.). (2010). Public policy for academic quality: Analyses of innovative policy instruments (Vol. 30). Springer Science \& Business Media.

9. Aamodt, P.O., Frølich, N., \& Stensaker, B. (2018). Learning outcomes-a useful tool in quality assurance? Views from academic staff. Studies in Higher Education, 43(4), 614-624. doi.org/10.108 $0 / 03075079.2016 .1185776$.

10. Lile, R., \& Bran C. (2014). The Assessment of Learning Outcomes. Procedia - Social and Behavioral Sciences, 163, 125-131. doi.org/10.1016/j.sbspro.2014.12.297 https://www.sciencedirect.com/ science/article/pii/S1877042814063988.

11. Aziz, A.A., Yusof, K.M., \& Yatim, J.M. (2012). Evaluation on the effectiveness of learning outcomes from students' perspectives. Procedia-Social and Behavioral Sciences, 56, 22-30. https://www. sciencedirect.com/science/article/pii/S1877042812040906.

12. Deros, B.M., Saibani, N., Yunos, B., Rahman, M.N.A., \& Ghani, J.A. (2012). Evaluation of training effectiveness on advanced quality management practices. Procedia-Social and Behavioral Sciences, 56, 67-73. https://www.sciencedirect.com/science/article/pii/S1877042812040955. 